\title{
Progesterone increases photochemical efficiency of photosystem II in wheat under heat stress by facilitating D1 protein phosphorylation
}

\author{
R. L. XUE ${ }^{*, * *}$, S. Q. WANG ${ }^{* *}$, H. L. XU ${ }^{* *}$, P. J. ZHANG ${ }^{* *}$, H. LI"**, and H. J. ZHAO ${ }^{* * * * * *,+}$ \\ College of Agronomy, Henan Agricultural University, Zhengzhou, 450002, China* \\ College of Life Sciences, Henan Agricultural University, Zhengzhou, 450002, China** \\ State Key Laboratory of Wheat and Maize Crop Science, Henan Agricultural University, Zhengzhou, 450002, China***
}

\begin{abstract}
Experiments were conducted to investigate the effects of exogenous progesterone on photochemical efficiency of PSII and turnover of D1 protein under heat stress during the grain-filling stage. Heat stress resulted in increases of hydrogen peroxide production, malondialdehyde content, and relative electrolytic leakage in wheat leaves, but these responses were alleviated by foliar application of progesterone. Meanwhile, activities of superoxide dismutase, catalase, and peroxidase were significantly improved in progesterone-pretreated leaves. Along with the alleviation of oxidative stress, higher abundances of STN8 and phosphorylated D1 protein and lower total D1 protein content in the PSII reactive center were observed in progesterone-pretreated leaves relative to controls. Consequently, progesterone raised the potential photochemical efficiency, actual photochemical efficiency, and electron transfer rate. These results indicate that foliar application of progesterone can effectively alleviate heat-induced PSII damage by enhancing antioxidant capability and regulating phosphorylation of D1 protein in wheat leaves.
\end{abstract}

Additional key words: antioxidant enzymes; cellular damage; high temperature; photosynthetic efficiency.

\section{Introduction}

Because of the threat of global warming and climate changes, heat stress has become one of the most serious constraints facing agriculture today, and climate change has already affected crop production worldwide (Wahid et al. 2007). Wheat, an important chimonophilous agricultural crop in northern China, is rather sensitive to heat stress, especially during the grain-filling stage. Continental hot and dry winds (Yang et al. 2006) cause damage to photosynthetic machinery, early decline of leaf function, stunting of seed development, and reduced wheat yield (Zhao et al. 2011).

Extensive studies have confirmed that PSII is one of the primary sites of damage under various kinds of stresses and that D1 proteins in the PSII reaction center are the main target of heat stress (Berry and Björkman 1980, Powles 1984, Barber and Andersson 1992, Aro et al. 1993, Niyogi 1999, Yamamoto 2001). Once D1 proteins are damaged, the assembly of PSII complexes is affected and electron transport is disrupted (Yamamoto et al. 2008). Accordingly, damage and turnover of D1 proteins during photoinhibition of PSII has been studied extensively, revealing much about the process (Barber et al. 1992, Aro et al. 1993). First, the damaged D1 proteins must be phosphorylated, which contributes to PSII machinery migrating from grana to stroma lamellas, and then, the damaged D1 protein can be degraded by proteases and removed from PSII for repair. Finally, a new D1 protein is reassembled into PSII, and the recovery cycle of PSII is complete (Aro et al. 1993, Tikkanen et al. 2008, Kato et al. 2009, Samol et al. 2012, Nath et al. 2013, Kato and Sakamoto 2014). Recent studies have suggested that the kinase STN8 catalyzes phosphorylation of D1 proteins and plays an important role in the repair of PSII under abiotic stress conditions (Pesaresi et al. 2011, Samol et al. 2012).

One way how to improve crops resistance to abiotic stresses is application of exogenous chemical substances

Received 15 August 2016, accepted 27 October 2016, published as online-first 8 December 2016.

${ }^{+}$Corresponding author; phone: 0086(0)371 63555790, fax:0086(0)37163555790, e-mail: zhaohj318@163.com

Abbreviations: CAT - catalase; Chl - chlorophyll; ETR - electron transfer rate; $\mathrm{F}_{\mathrm{o}}$ - minimal fluorescence yield of the dark-adapted state; $F_{m}$ - maximal fluorescence yield of the dark-adapted state; $F_{m}$ - maximal fluorescence yield of the light-adapted state; $F_{t}-$ steadystate fluorescence; $\mathrm{F}_{\mathrm{v}}$ - variable fluorescence; $\mathrm{F}_{\mathrm{v}} / \mathrm{F}_{\mathrm{m}}$ - maximal quantum yield of PSII photochemistry; MDA - malondialdehyde; MSH - mammalian sex hormone; POD - peroxidase; REC - relative electrical conductivity; ROS - reactive oxygen species; SDS - sodium dodecyl sulfate; SOD - superoxide dismutase; ФPSI - effective quantum yield of PSII photochemistry.

Acknowledgements: This research was supported by the fund of the State Key Laboratory of Wheat and Maize Crop Science (SKL2014KF-06) and Agricultural Science and Technology Research Project of Henen Province, China (132102110125). 
and plant growth regulators. Many studies have shown that steroid hormones are involved in the regulation of plant growth processes (Helmkamp and Bonner 1953, Dogra and Kaur 1994). For example, progesterone, a mammalian sex hormone (MSH), is naturally present in plants and involved in regulation of plant growth (Janeczko et al. 2013). Progesterone can stimulate the growth of sunflower seedling stem tissue (Dogra and Thukral 1991), Arabidopsis, and wheat roots (Geuns 1978). Moreover, application of MSHs, including progesterone, significantly reduced the effects of salt stress on wheat seedlings (Erdal 2012) as well as increased protein, sugar, and proline content throughout corn seed germination under salt stress (Mittler 2006, Erdal 2012) and stimulated antioxidant enzyme activity, reduced cell membrane permeability, and

\section{Materials and methods}

Plant and treatments: Wheat (Triticum aestivum L. cv. 'Aikang 58') seeds were surface sterilized with hydrogen peroxide, placed on wet filter papers in a Petri dish, and sprouted under thermostatic cultivation at a constant $28^{\circ} \mathrm{C}$ for three days. Afterwards, seedlings were moved to a greenhouse and cultured in $1 / 2$ - strength Hoagland nutrient solution, which was changed every two days. Two weeks improved the efficiency of PSII (Foyer et al. 1997, Janeczko et al. 2005). The study of vernalization of winter wheat found that progesterone-binding sites exist in both the cytoplasm and cell membrane (Janeczko et al. 2013). Recent experiments have demonstrated that exogenous progesterone alleviates heat and high light-induced inactivation of PSII in wheat by enhancing antioxidant defense and D1 protein stability (Su et al. 2014). In order to further elucidate the possible protective mechanisms of progesterone affecting the photosynthetic apparatus of wheat leaves under heat stress, the changes in antioxidant enzyme activities, production of $\mathrm{H}_{2} \mathrm{O}_{2}$, and content of both STN8 proteins and phosphorylated D1 proteins, the photochemical efficiency of PSII in the absence and presence of progesterone were investigated.

\begin{tabular}{lll}
\hline Group & Treatment & \\
\hline Control & $\mathrm{H}_{2} \mathrm{O}$ & Moderate temperature $\left(25^{\circ} \mathrm{C}\right)$ for $2 \mathrm{~h}$ \\
$\mathrm{H}$ & $\mathrm{H}_{2} \mathrm{O}$ & Heat stress $\left(36^{\circ} \mathrm{C}\right)$ for $2 \mathrm{~h}$ \\
$\mathrm{P}$ & Progesterone $1 \mu \mathrm{mol} \mathrm{L}-1$ & Moderate temperature $\left(25^{\circ} \mathrm{C}\right)$ for $2 \mathrm{~h}$ \\
$\mathrm{P}+\mathrm{H}$ & Progesterone $1 \mu \mathrm{mol} \mathrm{L}$ & Heat stress $\left(36^{\circ} \mathrm{C}\right)$ for $2 \mathrm{~h}$ \\
\hline
\end{tabular}

Hydrogen peroxide, malondialdehyde and the relative electrical conductivity: $\mathrm{H}_{2} \mathrm{O}_{2}$ was measured colorimetrically as described by Jana and Chaudhuri (1981). The concentration of $\mathrm{H}_{2} \mathrm{O}_{2}$ was monitored (UV-Vis spectrophotometer 754, Hengping, China) at $410 \mathrm{~nm}$ and calculated using the extinction coefficient of $0.28 \mathrm{mmol}^{-1}$ $\mathrm{L} \mathrm{cm}{ }^{-1}$. The content of $\mathrm{H}_{2} \mathrm{O}_{2}$ was expressed as $\mu \mathrm{mol} \mathrm{\textrm {g } ^ { - 1 }}$ (dry mass, DM). Malondialdehyde (MDA) content was measured according to Heath and Packer (1968) using the thiobarbituric acid (TBA) test, which determines MDA as an end product of lipid peroxidation. Absorbancy was measured at $532 \mathrm{~nm}$ corrected for nonspecific turbidity by subtracting the absorbancy at $600 \mathrm{~nm}$. The amount of MDA-TBA complex was calculated from the extinction coefficient $155 \mathrm{mmol}^{-1} \mathrm{~L} \mathrm{~cm}^{-1}$. (UV-Vis spectrophotometer 754, Hengping, China). The content of MDA was expressed as nmol g ${ }^{-1}(\mathrm{DM})$.

Relative electrical conductivity (REC) was measured using conductivity meter (TM-03, Leici, Shanghai, China), and calculated according to the method as described by $\mathrm{Li}$ (2000). Electrical conductivity (initial EC) of solution was measured first, then samples were heated to $100^{\circ} \mathrm{C}$ for $20 \mathrm{~min}$, and electrical conductivity (final EC) was later (at the three-leaf stage), the seedlings were sprayed with distilled water plus $0.01 \%$ Tween-20 as a control or $1 \mu \mathrm{mol} \mathrm{L} \mathrm{L}^{-1}$ progesterone solution with $0.01 \%$ Tween-20, for three days. The experiment consisted of four specific treatments (see the text table below). Wheat leaves were immediately harvested after treatment for various assays. measured again. Membrane permeability was calculated as the percentage of initial EC divided by final EC.

Antioxidant enzyme activities: Superoxide dismutase (SOD, EC 1.15.1.1) activity was assayed according to the method developed by Beauchamp and Fridovich (1971). The supernatant was incubated in an assay medium containing $50 \mathrm{mmol} \mathrm{L}^{-1}$ sodium phosphate buffer ( $\mathrm{pH} 7.8$ ), $13 \mathrm{mmol} \mathrm{L}{ }^{-1}$ methionine, $75 \mathrm{mmol} \mathrm{L}^{-1} \mathrm{NBT}$ (nitroblue tetrazolium), $2 \mu \mathrm{mol} \mathrm{L}-1$ riboflavin, and $100 \mathrm{nmol} \mathrm{L}^{-1}$ ethylene diamine tetraacetic acid (EDTA). Changes in absorbance were monitored at $470 \mathrm{~nm}$. One unit of SOD activity was defined as the amount of enzyme required to cause $50 \%$ inhibition of NBT reduction under light. Catalase (CAT, EC 1.11.1.6) activity was determined using the method developed by Havir and McHale (1987), which monitors the degradation of $\mathrm{H}_{2} \mathrm{O}_{2}$ at $240 \mathrm{~nm}$. One unit of CAT activity was defined as the amount of enzyme required to decompose one micromole of $\mathrm{H}_{2} \mathrm{O}_{2}$ per min at $25^{\circ} \mathrm{C}$. Peroxidase (POD, EC 1.11.1.7) activity was assayed according to the methods of Obinger et al. (1997). The reaction mixture contained $10 \mathrm{mmol} \mathrm{L^{-1 }}$ potassium phosphate buffer $(\mathrm{pH}=7), 5 \mathrm{mmol} \mathrm{L} \mathrm{L}^{-1} \mathrm{H}_{2} \mathrm{O}_{2}, 4 \mathrm{mM}$ 
guaiacol and the enzyme extract. For the estimation of POD activity, the increase in absorbance at $470 \mathrm{~nm}$ during the polymerisation of guaiacol to tetraguaiacol was recorded for $3 \mathrm{~min}$ and POD-specific activity was calculated using the extinction coefficient of $26.6 \mathrm{mmol}^{-1}$ $\mathrm{L} \mathrm{cm}{ }^{-1}$ for guaiacol. One unit of DOD activity was considered the enzyme amount capable of oxidising $1 \mu \mathrm{mol} \mathrm{L}{ }^{-1}$ guaiacol to tetraguaiacol per min. The activity of enzymes was expressed as unit $\mathrm{mg}^{-1}$ (protein).

Chlorophyll (Chl) fluorescence parameters were measured using the portable modulated $\mathrm{Chl}$ fluorometer (MINI-PAM-II, Walz, Germany). Leaves were darkadapted for $20 \mathrm{~min}$ before measurement. Actinic light intensity was $400 \mu \mathrm{mol}$ (photon) $\mathrm{m}^{-2} \mathrm{~s}^{-1}$ and saturated flash intensity was $8,000 \mu \mathrm{mol}\left(\right.$ photon) $\mathrm{m}^{-2} \mathrm{~s}^{-1} \cdot \mathrm{F}_{\mathrm{v}} / \mathrm{F}_{\mathrm{m}}$ was calculated as $\mathrm{F}_{\mathrm{v}} / \mathrm{F}_{\mathrm{m}}=\left[\left(\mathrm{F}_{\mathrm{m}}-\mathrm{F}_{\mathrm{o}}\right) / \mathrm{F}_{\mathrm{m}}\right]$, and $\Phi_{\text {PSII }}$ was calculated as $\Phi_{\text {PSII }}=\left[\left(\mathrm{F}_{\mathrm{m}}{ }^{\prime}-\mathrm{F}_{\mathrm{t}}\right) / \mathrm{F}_{\mathrm{m}}{ }^{\prime}\right]$, ETR was calculated as $\mathrm{ETR}=\left[\mathrm{PAR} \times 0.84 \times \Phi_{\mathrm{PSII}}\right]$, where PAR is the photosynthetically active radiation. For each measurement, five replicates were performed, and the results are expressed as means \pm standard deviations.

Extraction of thylakoid membrane proteins and Western blot analysis: The thylakoid membrane proteins were extracted as described in previous reports ( $\mathrm{Su}$ et al. 2014). Leaves were ground in liquid nitrogen into a fine powder and homogenized very well in ice-cold extraction buffer (Hepes $50 \mathrm{mmol} \mathrm{L}^{-1}(\mathrm{pH} 7.5), 10 \mathrm{mmol}(\mathrm{NaF}) \mathrm{L}^{-1}$,

\section{Results}

Photochemical efficiency of PSII: Among the various components of the photosynthesis machinery, PSII is particularly sensitive to heat, and even a short period of exposure to high temperatures irreversibly inactivates the PSII complex (Nash et al. 1985, Enami et al. 1994). $\mathrm{F}_{\mathrm{v}} / \mathrm{F}_{\mathrm{m}}$, $\Phi_{\text {PSII, }}$ and ETR declined under heat stress, indicating that heat stress damaged the photosynthetic apparatus (Table 1). However, progesterone-pretreated leaves under heat stress maintained higher values of these parameters, which were close to those of the control treatment. Overall, application of exogenous progesterone improved photochemical efficiency of PSII in wheat leaves subjected to heat stress.

$\mathrm{H}_{2} \mathrm{O}_{2}$, lipid peroxidation and cell membrane permeability: Heat stress caused significant increases in $\mathrm{H}_{2} \mathrm{O}_{2}$, with a mean $\mathrm{H}_{2} \mathrm{O}_{2}$ content which was 1.51 times that of the control (Table 2). However, progesterone pretreatment significantly reduced the ROS content under heat stress, with a mean $\mathrm{H}_{2} \mathrm{O}_{2}$ content that was only 1.16 times that of the control. Heat treatment also elevated MDA content markedly, to a level that was $79.2 \%$ higher than that of the control (Table 2). However, the MDA content of leaves subjected to heat stress was remarkably reduced by progesterone pretreatment (Table 2). In addition, although the relative electrical conductivity significantly increased
$5 \mathrm{mmol} \mathrm{L}^{-1} \mathrm{MgCl}_{2}$, and $0.33 \mathrm{~mol} \mathrm{~L}^{-1}$ sorbitol). Then, the homogenate was filtered through three layers of gauze, centrifuged at $6,000 \times g$ for $5 \mathrm{~min}$, and precipitated with $50 \mathrm{mmol} \mathrm{L}^{-1}$ Hepes ( $\mathrm{pH}$ 7.5). Next, the precipitate was washed with $10 \mathrm{mmol} \mathrm{L}^{-1} \mathrm{NaF}$ and $5 \mathrm{mmol} \mathrm{L}^{-1} \mathrm{MgCl}_{2}$ and centrifuged at $3,000 \times g$ for $3 \mathrm{~min}$. Finally, the thylakoid membrane pellet was resuspended in the storage buffer [50 mmol L ${ }^{-1}$ Hepes (pH 7.5), $10 \mathrm{mmol} \mathrm{L}^{-1} \mathrm{NaF}, 10 \mathrm{mmol}$ $\mathrm{L}^{-1} \mathrm{MgCl}_{2}$, and $0.1 \mathrm{~mol} \mathrm{~L}^{-1}$ sorbitol].

For the Western blot assay, the thylakoid membrane fraction ( $15 \mu \mathrm{g}$ of protein) was separated by $15 \%$ SDSPAGE using small vertical electrophoresis apparatus (1658001, Bio-Rad, Hercules, USA) and subjected to immunodetection as previously described (Callahan et al. 1990, Guo et al. 2006). Immunodetection of STN8 protein, D1 protein, and phosphorylated D1 protein were respectively conducted with polyclonal antibody raised against the STN8 protein, D1 protein, and phosphorylated D1 protein (anti-STN8, anti-PsbA, and phosphorylated antiPsbA, respectively, Agrisera Company, Vännäs, Sweden).

Statistical analysis: All data are reported as means \pm standard errors (SE) of three replicates. Statistical analysis was carried out using SPSS Statistics 18.0 software (IBM Corporation, USA). One-way analysis of variance $(A N O V A)$ was carried out with all the data to confirm the variability of data and validity of results. Comparisons among the mean values were made using the least significant difference (LSD) at a 0.05 probability level.

under heat stress compared to the control (by 1.85 times), this effect was completely alleviated by application of progesterone (to 0.99 times that of the control; Table 2). These results suggested that exogenous progesterone application protected wheat leaves from oxidative damage under heat stress.

Table 1. Effects of exogenous progesterone on maximal quantum yield of PSII photochemistry $\left(\mathrm{F}_{\mathrm{v}} / \mathrm{F}_{\mathrm{m}}\right)$ and effective quantum yield of PSII photochemistry ( $\Phi_{\text {PSII }}$ ) and the electron transfer rate (ETR) of PSII in wheat leaves under heat stress. Values are means \pm SD. Values labeled by different letters in the same column indicate statistically significant differences $(p<0.05)$.

\begin{tabular}{llll}
\hline Treatment & $F_{\mathrm{v}} / \mathrm{F}_{\mathrm{m}}$ & ФPSII & ETR \\
\hline Control & $0.8058 \pm 0.0089^{\mathrm{a}}$ & $0.2047 \pm 0.0326^{\mathrm{b}}$ & $90.79 \pm 7.63^{\mathrm{b}}$ \\
$\mathrm{H}$ & $0.5982 \pm 0.0218^{\mathrm{b}}$ & $0.1588 \pm 0.0278^{\mathrm{c}}$ & $68.32 \pm 9.66^{\mathrm{c}}$ \\
$\mathrm{P}$ & $0.7984 \pm 0.0289^{\mathrm{a}}$ & $0.2234 \pm 0.0159^{\mathrm{a}}$ & $98.33 \pm 8.89^{\mathrm{a}}$ \\
$\mathrm{P}+\mathrm{H}$ & $0.7635 \pm 0.096^{\mathrm{a}}$ & $0.1944 \pm 0.0189^{\mathrm{b}}$ & $87.56 \pm 8.64^{\mathrm{b}}$ \\
\hline
\end{tabular}

Antioxidative enzyme activities: The activity of SOD, CAT, and POD increased slightly, but insignificantly, under heat stress compared with the control (Table 3). In comparison with the control treatment, progesterone pretreatment significantly elevated the activities of all 
three antioxidant enzymes (SOD, CAT, and POD) under heat stress. These results indicated that exogenous progesterone application enhanced antioxidant defense of wheat under heat stress.

STN8: Expression of STN8 was reduced under heat stress, to only $84.5 \%$ that of the control (Fig. $1 B$ ). However, this reduction was alleviated by pretreatment with progesterone, resulting in slight increases in the relative content of STN8 proteins under both heat stress $(101 \%$ of the control level) and normal conditions (106\% of the control level).

D1 protein: Heat stress induced decreases in relative content of D1 protein (to $64.5 \%$ of the control) (Fig. $2 B$ ).

Table 2. Effects of exogenous progesterone on $\mathrm{H}_{2} \mathrm{O}_{2}$ and malondialdehyde content (MDA), and the relative electrical conductivity (REC) of wheat leaves under heat stress. Values are means \pm SD. Values labeled by different letters in the same column indicate statistically significant differences $(p<0.05)$.

\begin{tabular}{|c|c|c|c|}
\hline Treatment & $\mathrm{H}_{2} \mathrm{O}_{2}\left[\mu \mathrm{mol} \mathrm{g}{ }^{-1}(\mathrm{DM})\right]$ & MDA $\left[\mathrm{nmol} \mathrm{g}^{-1}(\mathrm{DM})\right]$ & $\operatorname{REC}[\%]$ \\
\hline Control & $480.3 \pm 39.78^{\mathrm{bc}}$ & $42 \pm 5.20^{\mathrm{c}}$ & $15.2 \pm 0.3055^{\mathrm{b}}$ \\
\hline $\mathrm{H}$ & $725.4 \pm 56.74^{\mathrm{a}}$ & $83 \pm 2.65^{\mathrm{a}}$ & $28.1 \pm 0.8030^{\mathrm{a}}$ \\
\hline $\mathrm{P}$ & $402.6 \pm 28.92^{c}$ & $40 \pm 4.36^{\mathrm{cd}}$ & $14.3 \pm 0.5000^{\mathrm{c}}$ \\
\hline $\mathrm{P}+\mathrm{H}$ & $560.9 \pm 30.31^{\mathrm{d}}$ & $55 \pm 5.29^{b}$ & $15.1 \pm 0.4995^{\mathrm{b}}$ \\
\hline
\end{tabular}

In leaves pretreated with progesterone, D1 protein abundance increased under the normal condition (to 106\% of the control), but decreased under heat stress (to $33.5 \%$ of the control).

\section{Discussion}

Heat stress is one of the most serious constraints facing agriculture today. When wheat plants suffer from high temperature stress, reactive oxygen species (ROS) such as superoxide $\left(\mathrm{O}_{2}^{-}\right)$, singlet oxygen $\left({ }^{1} \mathrm{O}_{2}\right)$, hydrogen peroxide $\left(\mathrm{H}_{2} \mathrm{O}_{2}\right)$, and hydroxyl radicals $(\mathrm{OH})$ are overproduced, thus resulting in lipid peroxidation and cellular damage (Bowler et al. 1992, Singh et al. 2001 ). Meanwhile, the activities of antioxidant enzymes are induced to reduce ROS under heat stress (Rainwater et al. 1996, Jiang and Huang 2001, Vacca et al. 2004). In order to cope with heat stress, some mechanical, chemical, and biological approaches are being researched and implemented. Janeczko et al. (2013) reported that progesterone pretreatment decreased elevated leakage in Arabidopsis thaliana caused by mutant and saprophytic bacteria. It has been also found very recently that progesterone in plants can stimulate the activity of antioxidative enzymes under normal conditions or strong heat and high light stress (Erdal and Dumlupinar 2011, Su et al. 2014). Consistent with these reports, the current study showed that heat stress significantly increased the generation of $\mathrm{H}_{2} \mathrm{O}_{2}$, thus increasing MDA content and relative electrical conductivity in wheat leaves (Table 2). However, the activities of SOD, CAT, and POD were increased by progesterone pretreatment (Table 3), which decreased $\mathrm{H}_{2} \mathrm{O}_{2}$ accumulation and mitigated lipid peroxidation. In brief, progesterone alleviated oxidative damage induced by heat stress in wheat by stimulating the antioxidant defense system.
Phosphorylated D1 protein was reduced to $67.5 \%$ of the control under heat stress, but this reduction was counteracted by pretreatment with progesterone, leading to a substantial increase in the content of phosphorylated D1 protein (to $400 \%$ of the control) (Fig. $3 B$ ).

It has been previously shown that ROS are responsible for heat-induced damage to PSII (Yamashita et al. 2008). Exogenous progesterone reduced ROS production under heat stress (Table 2). Theoretically, this might alleviate heat-induced inactivation of PSII, a protein complex composed of more than 25 different subunits, in which D1 protein is a target component damaged by many environmental stresses. Hence, an efficient PSII-repair cycle was required to regain the function of PSII (Yamamoto et al 2008). More recently, it has been suggested that phosphorylation of PSII reaction center protein D1 is a prerequisite for efficient migration of damaged PSII complexes from grana to stroma lamellae for repair (Tikkanen et al. 2008). Only when the repair rate equals the damage rate, photoinhibition is averted. In chloroplasts, STN8 and STN7 are the protein kinases responsible for phosphorylation of core proteins in PSII; they play an important role in the regulation of state transitions and energy distribution between PSII and PSI (Bellafiore et al. 2005, Depège et al. 2003, Vainonen et al. 2005). The STN8 protein kinase is specifically responsible for D1 protein phosphorylation. In this report, expression of STN8 was reduced under heat stress (Fig. 1B), however, this reduction was alleviated by pretreatment with progesterone. Similarly to this, abundances of phosphorylated D1 proteins were significantly elevated to $400 \%$ of the control level under heat stress by exogenous progesterone application (Fig. $3 B$ ), indicating that the 
Table 3. Effects of exogenous progesterone on activities of catalase (CAT, EC 1.11.1.6), superoxide dismutase (SOD, EC 1.15.1.1) and peroxidase (POD, EC 1.11.1.7) in wheat leaves under heat stress. Values are means \pm SD. Values labeled by different letters in the same column indicate statistically significant differences $(p<0.05)$.

\begin{tabular}{llll}
\hline Treatment & CAT $\left[\mathrm{U} \mathrm{mg}^{-1}\right.$ (protein) $]$ & $\mathrm{SOD}\left[\mathrm{U} \mathrm{mg}^{-1}\right.$ (protein) $]$ & POD $\left[\mathrm{U} \mathrm{mg}^{-1}\right.$ (protein) $]$ \\
\hline Control & $11.1 \pm 0.4726^{\mathrm{c}}$ & $18.3 \pm 0.7008^{\mathrm{c}}$ & $2.9 \pm 0.3606^{\mathrm{c}}$ \\
$\mathrm{H}$ & $12.5 \pm 0.5009^{\mathrm{b}}$ & $19.4 \pm 0.4012^{\mathrm{bc}}$ & $3.2 \pm 0.2003^{\mathrm{bc}}$ \\
$\mathrm{P}$ & $11.9 \pm 0.2002^{\mathrm{b}}$ & $20.1 \pm 1.7321^{\mathrm{b}}$ & $3.4 \pm 0.2646^{\mathrm{b}}$ \\
$\mathrm{P}+\mathrm{H}$ & $17.8 \pm 0.5292^{\mathrm{a}}$ & $24.7 \pm 0.3001^{\mathrm{a}}$ & $4.0 \pm 0.1732^{\mathrm{a}}$ \\
\hline
\end{tabular}

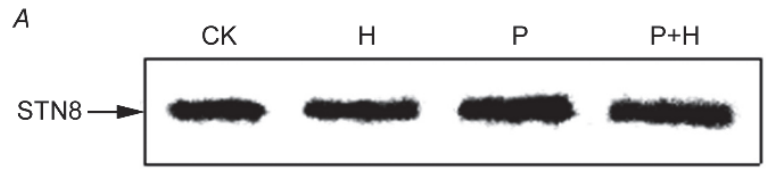

B

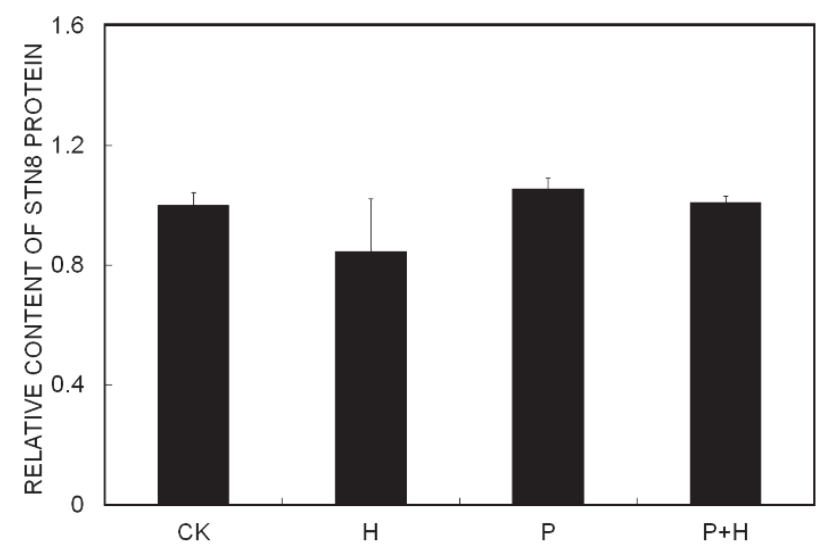

Fig. 1. Western blot $(A)$ and relative content of STN8 $(B)$ in wheat leaves under each of the treatments. CK - control leaves pretreated with water under a moderate temperature $\left(25^{\circ} \mathrm{C}\right) ; \mathrm{H}-$ leaves pretreated with water and exposed to heat $\left(36^{\circ} \mathrm{C}\right)$ for $2 \mathrm{~h}$; $\mathrm{P}$ - leaves pretreated with progesterone under a moderate temperature $\left(25^{\circ} \mathrm{C}\right)$ for $2 \mathrm{~h} ; \mathrm{P}+\mathrm{H}-$ leaves pretreated with progesterone and exposed to heat $\left(36^{\circ} \mathrm{C}\right)$ for $2 \mathrm{~h}$. Values are means $\pm \mathrm{SD}$.

process of $\mathrm{D} 1$ protein phosphorylation was promoted by exogenous progesterone. Accordingly, the content of nonphosphorylated D1 protein decreased to $33.5 \%$ of the control by progesterone treatment under heat stress (Fig. $2 B$ ). However, Su et al. (2014) have demonstrated that heat and light stress caused a notable decrease in content of D1 protein in wheat leaves, but progesterone pretreatment maintained the content of D1 protein at a high level. Li et al. (2015) showed that $\mathrm{H}_{2} \mathrm{~S}$ induced fast $\mathrm{D} 1$ protein synthesis (high expression of $P s b A$ ) under drought stress in wheat. According to this, higher D1 protein accumulation compared with control, under heat and light stress and when pretreated with progesterone, might result from promotion of de novo synthesis of D1 protein. In current study, since the process of D1 protein phosphorylation is required for D1 turnover cycle, the elevated D1 protein phosphorylation for D1 protein degradation might

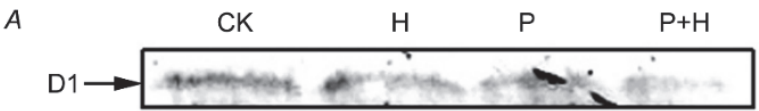

B

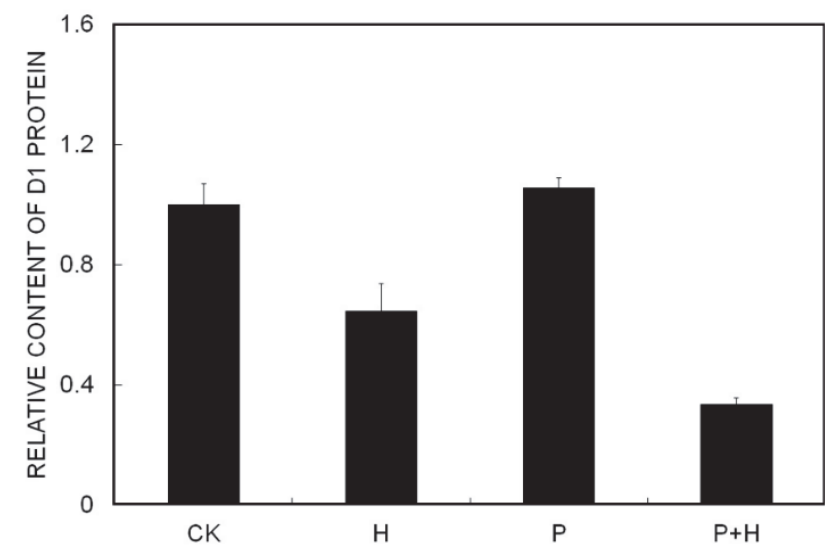

Fig. 2. Western blot $(A)$ and relative content of D1 protein $(B)$ in wheat leaves under each of the treatments. CK - control leaves pretreated with water under a moderate temperature $\left(25^{\circ} \mathrm{C}\right) ; \mathrm{H}-$ leaves pretreated with water and exposed to heat $\left(36^{\circ} \mathrm{C}\right)$ for $2 \mathrm{~h}$; P - leaves pretreated with progesterone under a moderate temperature $\left(25^{\circ} \mathrm{C}\right)$ for $2 \mathrm{~h} ; \mathrm{P}+\mathrm{H}$ - leaves pretreated with progesterone and exposed to heat $\left(36^{\circ} \mathrm{C}\right)$ for $2 \mathrm{~h}$. Values are means $\pm \mathrm{SD}$.

be the reason why D1 protein content significantly decreased. In other words, more D1 proteins were phosphorylated for migration, repair, and degradation and replaced by a newly synthesized D1 protein. The results suggested that increased phosphorylated D1 protein levels improved the stability and rapid repair of PSII by avoiding the net loss of D1 protein. Thus, $\mathrm{F}_{\mathrm{v}} / \mathrm{F}_{\mathrm{m}}, \Phi_{\mathrm{PSII}}$, and ETR in leaves subjected to heat stress were markedly improved by progesterone pretreatment (Table 1). It means that progesterone alleviated heat-induced PSII damage by facilitating D1 protein turnover rather than D1 protein accumulation.

In general, exogenous application of progesterone enhanced antioxidant defenses by simulating the activities of CAT, POD, and SOD and reducing oxidative damage to cells of wheat leaves. At the same time, exogenous progesterone increased photochemical efficiency of PSII in wheat plants subjected to heat stress by increasing the 


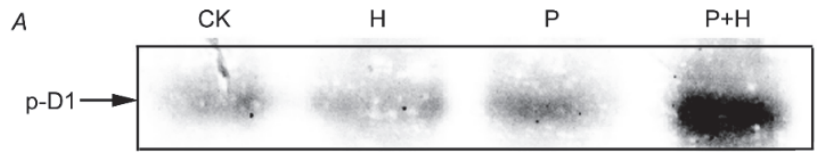

B

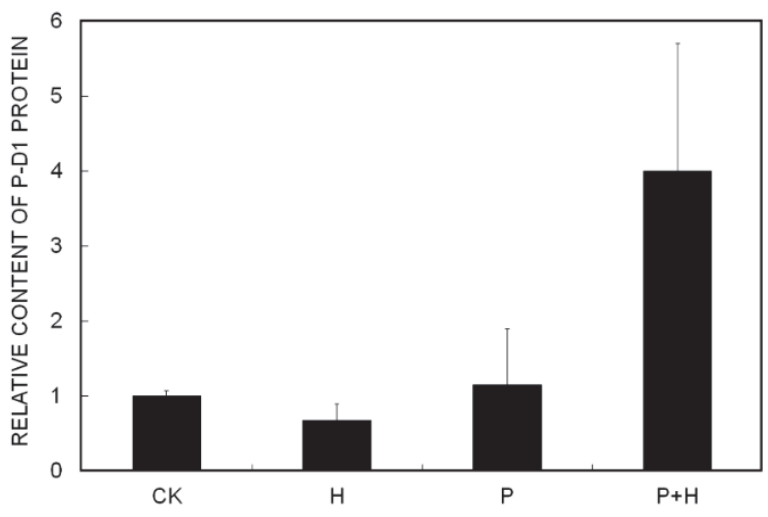

\section{References}

Aro E. M., Virgin I., Andersson B.: Photoinhibition of photosystem II. Inactivation, protein damage and turnover. Biochim. Biophys. Acta 1143: 113-134, 1993.

Barber J., Andersson B.: Too much of a good thing: light can be bad for photosynthesis. - Trends Biochem. Sci. 17: 61-66, 1992.

Beauchamp C., Fridovich I.: Superoxide dismutase:improved assays and an assay applicable to acrylamide gels. - Anal. Biochem. 44: 276-287, 1971.

Bellafiore S., Barneche F., Peltier G., Rochaix JD.: State transitions and light adaptation require chloroplast thylakoid protein kinase STN7. - Nature 433: 892-895, 2005.

Berry J., Björkman O.: Photosynthetic response and adaptation to temperature in higher plants. - Annu. Rev. Plant Physio. 31: 491-543, 1980.

Bowler C., Montagu M.V., Inze D.: Superoxide dismutase and stress tolerance. - Annu. Rev. Plant Phys. 43: 83-116, 1992.

Callahan F. E., Ghirardi M. L., Sopory S. K.et al.: A novel metabolic form of the $32 \mathrm{kDa}-\mathrm{D} 1$ protein in the grana-localized reaction center of photosystem II. - J. Biol. Chem. 265: 1535715360, 1990.

Depège N., Bellafiore S., Rochaix J.D.: Role of chloroplast protein kinase Stt7 in LHCII phosphorylation and state transition in Chlamydomonas. - Science 299: 1572-1575, 2003.

Dogra R., Kaur A.: Effect of steroids on some growth and biochemical parameters of Triticum aestivum L. during germination. - Crop Res. 8: 611-620, 1994.

Dogra R., Thukral A.K.: New Trends in Plant Physiology. Pp. 65-70. Today and Tomorrow's Printers and Publishers, New Delhi. 1991.

Enami I., Kitamura M., Tomo T. et al.: Is the primary cause of thermal inactivation of oxygen evolution in spinach PSII membranes release of the extrinsic $33 \mathrm{kDa}$ protein or of $\mathrm{Mn}$ ? Biochim. Biophys. Acta 1186: 52-58, 1994.

Erdal S.: Alleviation of salt stress in wheat seedlings by mammalian sex hormones. - J. Sci. Food Agr. 92: 1411-1416, 2012.
Fig. 3. Western blot $(A)$ and relative content of phosphorylated D1 protein $(B)$ in wheat leaves under each of the treatments. $\mathrm{CK}$ - control leaves pretreated with water under a moderate temperature $\left(25^{\circ} \mathrm{C}\right) ; \mathrm{H}$ - leaves pretreated with water and exposed to heat $\left(36^{\circ} \mathrm{C}\right)$ for $2 \mathrm{~h}$; $\mathrm{P}$ - leaves pretreated with progesterone under a moderate temperature $\left(25^{\circ} \mathrm{C}\right)$ for $2 \mathrm{~h}$; and $\mathrm{P}+\mathrm{H}-$ leaves pretreated with progesterone and exposed to heat $\left(36^{\circ} \mathrm{C}\right)$ for $2 \mathrm{~h}$. Values are means $\pm \mathrm{SD}$.

abundance of STN8 and promoting D1 protein phosphorylation.

As regards the mechanism of the stress protective effects of progesterone, many details are not clear yet. The recent study of Janeczko et al (2013) showed that progesterone can ameliorate the negative impact of biotic and abiotic stresses on PSII efficiency in Arabidopsis thaliana, but they do not influence it in nonstressed plants. Similar to this, in present study, it is noteworthy that progesterone pretreatment decreased the content of D1 protein and increased phosphorylated D1 proteins abundance under heat stress but not in case of progesterone treatment alone (Figs. $2 B, 3 B$ ), this problem would require further studies.

Erdal S., Dumlupinar R.: Mammalian sex hormones stimulate antioxidant system and enhance growth of chickpea plants. Acta Physiol. Plant. 33: 1011-1017, 2011.

Foyer C. H., Lopez-Delgado H., Dat J. F.et al.: Hydrogen peroxide- and glutathione-associated mechanisms of acclimatory stress tolerance and signalling. - Physiol. Plantarum 100: 241-254, 1997.

Geuns J.M.C.: Steroid hormones and plant growth and development. - Phytochemistry 17: 1-14, 1978

Guo J.W., Wei H.M., Wu S. F., Du L.F.: [Effects of low temperature on the distribution of excitation energy in photosystem and the phosphorylation of thylakoid membrane proteins in rice.] - Acta Biophys. Sin. 22: 197-202, 2006. [In Chinese]

Havir E.A., McHale N.A.: Biochemical and development characterization of multiple forms of catalase in tobacco leaves. - Plant Physiol. 84: 450-455, 1987.

Heath R.L., Packer L.: Photoperoxidation in isolated chloroplasts.I. Kinetics and stoichiometry of fatty acid peroxidation. - Arch. Biochem. Biophys. 125:189-198,1968.

Helmkamp G., Bonner J.: Some relationships of sterols to plant growth. - Plant Physiol. 28:428-436, 1953.

Jana S., Chaudhuri M.A.: Glycolate metabolism of three submerged aquatic angiosperms during aging. - Aquat. Bot. 12: 345$354,1981$.

Janeczko A., Oklešt'ková J., Siwek A. et al.: Endogenous progesterone and its cellular binding sites in wheat exposed to drought stress. - J. Steroid Biochem. 138: 384-394, 2013.

Janeczko A., Koscielniak J., Pilipowicz M. et al.: Protection of winter rape photosystem II by 24-epibrassinolide under cadmium stress. - Photosynthetica 43: 293-298, 2005.

Janeczko A., Tóbiás I., Skoczowski A. et al.: Progesterone moderates damage in Arabidopsis thaliana caused by infection with Pseudomonas syringae or $P$. fluorescens. - Biol. Plantarum 57: 169-173, 2013.

Jiang Y.W., Huang B.R.: Drought and heat stress injury to two 
cool-season turfgrasses in relation to antioxidant metabolism and lipid peroxidation. - Crop Sci. 41: 436-442, 2001.

Kato Y., Miura E., Ido K. et al.: The variegated mutants lacking chloroplastic FtsHs are defective in D1 degradation and accumulate reactive oxygen species. - Plant Physiol. 151: 1790$1801,2009$.

Kato Y., Sakamoto W.: Phosphorylation of photosystem II core proteins prevents undesirable cleavage of D1 and contributes to the fine-tuned repair of photosystem II. - Plant J. 79: 312321, 2014.

Li H.S., Sun Q., Zhao S.J.: Principle and Technology of Plant Physiology and Biochemical Experiments. Pp. 261-263. Higher Educ. Press, Beijing 2000.

Mittler R.: Abiotic stress, the field environment and stress combination. - Trend Plant Sci. 11: 15-19, 2006.

Nash D., Mitsue M., Murata N.: Heat inactivation of oxygen evolution in photosystem II particles and its acceleration by chloride depletion and exogenous manganese. - BBABioenergetics 807: 127-133, 1985.

Nath K., Poudyal R.S., Eom J.S., Park Y.S. et al.: Loss-offunction of OsSTN8 suppresses the photosystem II core protein phosphorylation and interferes with the photosystem II repair mechanism in rice (Oryza sativa). - Plant J. 76: 675-686, 2013.

Niyogi K.K.: Photoprotection revisited: genetic and molecular approaches. - Annu. Rev. Plant Phys. 50: 333-359, 1999.

Obinger C., Maj M., Nicholls P., Loewen P.: Activity, peroxide compound formation, and heme d synthesis in Escherichia coli HPII catalase. - Arch. Biochem. Biophys. 342: 58-67, 1997.

Pesaresi P., Pribil M., Wunder T., Leister D.: Dynamics of reversible protein phosphorylation in thylakoids of flowering plants: the roles of STN7, STN8 and TAP38. - Biochim. Biophys. Acta 1807: 887-896, 2011.

Powles S.B.: Photoinhibition of photosynthesis induced by visible light. - Annu. Rev. Plant Physio. 35: 15-44, 1984.

Rainwater D.T., Gossett D.R., Millhollon E.P. et al:: The relationship between yield and the antioxidant defence system in tomatoes grown under heat stress. - Free Radical Res. 25: 421-435, 1996.

Samol I., Shapiguzov A., Ingelsson B. et al.: Identification of a photosystem II phosphatase involved in light acclimation in Arabidopsis. - Plant Cell 24: 2596-2609, 2012.
Singh A.K., Singhal G.S.: Effect of irradiance on the thermal stability of thylakoid membrane isolated from acclimated wheat leases. - Photosynthetica 39: 23-27, 2001.

$\mathrm{Su}$ X.Y., Wu S., Yang L. et al.: Exogenous progesterone alleviates heat and high light stress-induced inactivation of photosystem II in wheat by enhancing antioxidant defense and D1 protein stability. - Plant Growth Regul. 74: 311-318, 2014.

Tikkanen M., Nurmi M., Kanqasjärvi S., Aro E.M.: Core protein phosphorylation facilitates the respair of photodamaged photosystem II at high light. - Biochim. Biophys. Acta 1777: 1432-1437, 2008.

Vacca R.A., de Pinto M.C., Valenti D. et al.: Production of reactive oxygen species, alteration of cytosolic ascorbate peroxidase, and impairment of mitochondrial metabolism are early events in heat shock-induced programmed cell death in tobacco Bright-Yellow 2 cells. - Plant Physiol. 134: 11001112,2004

Vainonen J.P., Hansson M., Vener A.V.: STN8 Protein kinase in Arabidopsis thaliana is specific in phosphorylation of photosystem II core proteins. - J. Biol. Chem. 280: 33679-33686, 2005.

Wahid A., Gelani S., Ashraf M., Foolad M.R.: Heat tolerance in plants:an overview. - Environ. Exp. Bot. 61: 199-223, 2007.

Yamamoto Y.: Quality control of photosystem II. - Plant Cell Physiol. 42: 121-128, 2001.

Yamamoto Y., Aminaka R., Yoshika M. et al.: Quality control of photosystem II: impact of light and heat stresses. - Photosynth. Res. 98: 589-608, 2008.

Yamashita A., Nijo N., Pospíśil P. et al.: Quality control of photosystem II: reactive oxygen species are responsible for the damage to photosystem II under moderate heat stress. - J. Biol. Chem. 283: 28380-28391, 2008.

Yang X.H., Chen X.Y., Ge Q.Y.et al.: Tolerance of photosynthesis to photoinhibition, high temperature and drought stress in flag leaves of wheat: A comparison between a hybridization line and its parents grown under field conditions. - Plant Sci. 171: 389-397, 2006.

Zhao H.J., Zhao X.J., Ma P.F. et al.: Effects of salicylic acid on protein kinase activity and chloroplast $\mathrm{D} 1$ protein degradation in wheat leaves subjected to heat and high light stress. - Acta Ecol. Sin. 31: 259-263, 2011. 